\title{
Estimating changes in Scottish soil carbon stocks using ECOSSE. II. Application
}

\author{
Jo Smith ${ }^{1, *}$, Pia Gottschalk ${ }^{1}$, Jessica Bellarby ${ }^{1}$, Stephen Chapman $^{2}$, Allan Lilly ${ }^{2}$, \\ Willie Towers ${ }^{2}$, John Bell ${ }^{2}$, Kevin Coleman ${ }^{3}$, Dali Nayak ${ }^{1}$, Mark Richards ${ }^{1}$, Jon Hillier ${ }^{1}$, \\ Helen Flynn $^{1}$, Martin Wattenbach ${ }^{1}$, Matt Aitkenhead ${ }^{1,2}{ }^{\text {, Jagadeesh Yeluripati }}{ }^{1}$, Jenny \\ Farmer $^{1}$, Ronnie Milne ${ }^{4}$, Amanda Thomson ${ }^{4}$, Chris Evans $^{5}$, Andy Whitmore ${ }^{3}$, \\ Pete Falloon ${ }^{6}$, Pete Smith ${ }^{1}$
}

${ }^{1}$ Institute of Biological \& Environmental Sciences, School of Biological Science, University of Aberdeen, 23 St. Machar Drive, Aberdeen AB24 3UU, UK

${ }^{2}$ Macaulay Land Use Research Institute, Craigiebuckler, Aberdeen AB15 8QH, UK

${ }^{3}$ Rothamsted Research, Harpenden, Hertfordshire AL5 2JQ, UK

${ }^{4}$ Centre for Ecology \& Hydrology, Bush Estate, Penicuik, Midlothian EH26 0QB, UK

${ }^{5}$ Centre for Ecology \& Hydrology, Environment Centre Wales, Deiniol Road, Bangor, Gwynedd LL57 2UW, UK

${ }^{6}$ Met Office Hadley Centre, FitzRoy Road, Exeter, Devon EX1 3PB, UK

\begin{abstract}
In order to predict the response of carbon (C)-rich soils to external change, models are needed that accurately reflect the conditions of these soils. Here we present an example application of the new Estimation of Carbon in Organic Soils - Sequestration and Emissions (ECOSSE) model to estimate net change in soil $\mathrm{C}$ in response to changes in land use in Scotland. The ECOSSE estimate of annual change in soil C stocks for Scotland between 2000 and 2009 is $-810 \pm 89 \mathrm{kt} \mathrm{yr}^{-1}$, equivalent to $0.037 \pm 0.004 \% \mathrm{yr}^{-1}$. Increasing the area of land-use change from arable to grass has the greatest potential to sequester soil $\mathrm{C}$, and reducing the area of change from grass to arable has the greatest potential to reduce losses of soil C. Across Scotland, simulated changes in soil C from C-rich soils (C content >6\%) between 1950 and 2009 is -63 Mt, compared with -35 Mt from non-C-rich mineral soils; losses from C-rich soils between 2000 and 2009 make up $64 \%$ of the total soil C losses. One mitigation option that could be used in upland soils to achieve zero net loss of C from Scottish soils is to stop conversion of semi-natural land to grassland and increase conversion of grassland to seminatural land by $125 \%$ relative to the present rate. Mitigation options involving forestry are not included here because the data available to calculate losses of soil $\mathrm{C}$ do not account for losses of soil $\mathrm{C}$ on drainage of semi-natural land.
\end{abstract}

KEY WORDS: Organic soils · Dynamics simulation modelling $\cdot$ Changes in soil C stocks $\cdot$ Land-use change $\cdot$ Climate change

\section{INTRODUCTION}

Accurate predictions of the effects of changes in climate and land use on greenhouse gas (GHG) emissions are vital for informing land-use policy. Peatlands, characterized as high carbon (C) soils, cover approximately 4 million $\mathrm{km}^{2}$ globally, with a total C stock estimated in 2008 to be $450 \mathrm{Pg} \mathrm{C}$ (Joosten 2009), and highly organic soils can make a significant contribution to national
GHG emissions. For example, $15 \%$ of Scotland's total GHG emissions come from land-use changes on Scotland's C-rich soils (Smith et al. 2007a). Therefore, it is essential that national simulations of changes in soil $\mathrm{C}$ stocks include accurate simulation of highly organic soils. However, the majority of models that are currently used to predict differences in soil $\mathrm{C}$ and nitrogen (N) caused by climate or land-use changes have been derived from models originally developed for mineral 
soils (Smith 2001). None of these models is entirely satisfactory for describing what happens to organic soils following land-use change (Smith et al. 2007a).

The Estimation of Carbon in Organic Soils - Sequestration and Emissions (ECOSSE) model (Smith et al. 2010a) has been developed to simulate the impacts of land use and climate change on GHG emissions from both mineral and organic soils. It is driven by commonly available meteorological, land-use and soil data, and was developed from concepts originally derived for mineral soils in the RothC (Jenkinson \& Rayner 1977, Jenkinson et al. 1987, Coleman \& Jenkinson 1996) and SUNDIAL (Bradbury et al. 1993, Smith et al. 1996a) models. Following these established models, ECOSSE uses a pool-type approach, describing soil organic matter (SOM) as pools of inert organic matter, humus, biomass, resistant plant material and decomposable plant material. The structure and formulation of ECOSSE are described in detail by Smith et al. (2010a,b [2010 in this Special]).

ECOSSE differs from RothC and SUNDIAL in the addition of a number of processes and impacts that are not crucial in the mineral arable soils that these models were originally developed for. More importantly, ECOSSE differs from RothC and SUNDIAL in the way that it makes full use of the limited information that is available to run models at the national scale. In particular, measurements of soil $\mathrm{C}$ are used to interpolate the activity of the SOM and the plant inputs needed to achieve those measurements. If data are available describing soil water, plant inputs, nutrient applications and timing of management operations, these can be used to drive the model and so better apportion the factors determining the interpolated activity of the SOM. However, if any of this information is missing, the model can still provide adequate simulations of SOM turnover, although the impact of changes in conditions will be estimated with less accuracy due to the reduced detail of the inputs.

The processes of $\mathrm{C}$ and $\mathrm{N}$ turnover in the soil are included in the model using only simple equations driven by readily available input variables. This not only ensures that the model remains functional for data-limited runs, but also allows it to be applied at both field and national scales, without a great loss of accuracy. Because it is able to function at both field and national scales, if the model is driven by appropriate input data, field-scale evaluations can be used to determine uncertainty in national simulations. In an evaluation of uncertainty in simulations driven only by the limited data available at a national scale, Smith et al. (2010b) concluded that simulated values show a high degree of association with the measurements in both total $\mathrm{C}$ and change in $\mathrm{C}$ content of the soil. Over all sites where land-use change occurred, the average deviation be- tween the simulated and the measured values of percentage change in soil $\mathrm{C}$ was less than the experimental error ( $11 \%$ simulation error, $53 \%$ measurement error), suggesting that the uncertainty in the national-scale simulations is $\sim 11 \%$. Only a small bias in the simulations compared to the measured values was observed, suggesting that a small underestimate of the change in soil C should be expected at the national scale $(-4 \%)$.

Here we present an example application of ECOSSE, using the $11 \%$ simulation error obtained by Smith et al. (2010b). The model is applied to national-scale simulations of changes in soil C stocks in Scotland. Scotland is a relatively small country $\left(\sim 78000 \mathrm{~km}^{2}\right)$, and so provides an ideal example for developing the capability to do simulations for larger countries using a dynamic model. The soils in Scotland range in organic C content from $<1 \%$ to almost $60 \%$ (Lilly et al. 2004), and so provide a good demonstration of the application of the model to simulate national emissions from soils with a range of $\mathrm{C}$ contents.

\section{METHODS}

\subsection{Approach used in national simulations of Scotland}

The ECOSSE model (Smith et al. 2010a,b) was used together with soils, land-use and weather data to simulate changes in soil $\mathrm{C}$ content across the whole of Scotland. As illustrated in Fig. 1, soil data were available on a $1 \mathrm{~km}^{2}$ grid across Scotland (Lilly et al. 2004), whereas weather data were available on a $5 \mathrm{~km}^{2}$ grid (http:// www.ukcip.org.uk/index.php?id=161\&option=com content\&task=view), and land-use and land-use change data were only available on a $20 \mathrm{~km}^{2}$ grid (Mobbs \& Dyson 2009, Thomson et al. unpubl. data). The same weather data were used for all twenty-five $1 \mathrm{~km}^{2}$ cells in each $5 \mathrm{~km}^{2}$ grid. The land-use and landuse change data were interpolated to a $1 \mathrm{~km}^{2}$ grid by assuming the patterns were uniform across all four hundred $1 \mathrm{~km}^{2}$ cells in the $20 \mathrm{~km}^{2}$ grid. If the land use was not reported as occurring on a particular soil type according to the Scottish Soils Database (Lilly et al. 2004), the model set all land-use changes to or from that land use to zero and increased the area of the land-use change occurring on the other soil types within the $1 \mathrm{~km}^{2}$ cell in proportion to the area of the soil type. If the land use was not reported on any of the other soil types in the cell, the land-use change was assumed to be absent from that $1 \mathrm{~km}^{2}$ cell and was spread evenly across the other $1 \mathrm{~km}^{2}$ cells in the $20 \mathrm{~km}^{2}$ grid cell. This allowed results to be reported on a $1 \mathrm{~km}^{2}$ grid, while avoiding unrealistic land uses on a given soil, such as arable crops on blanket peat. 


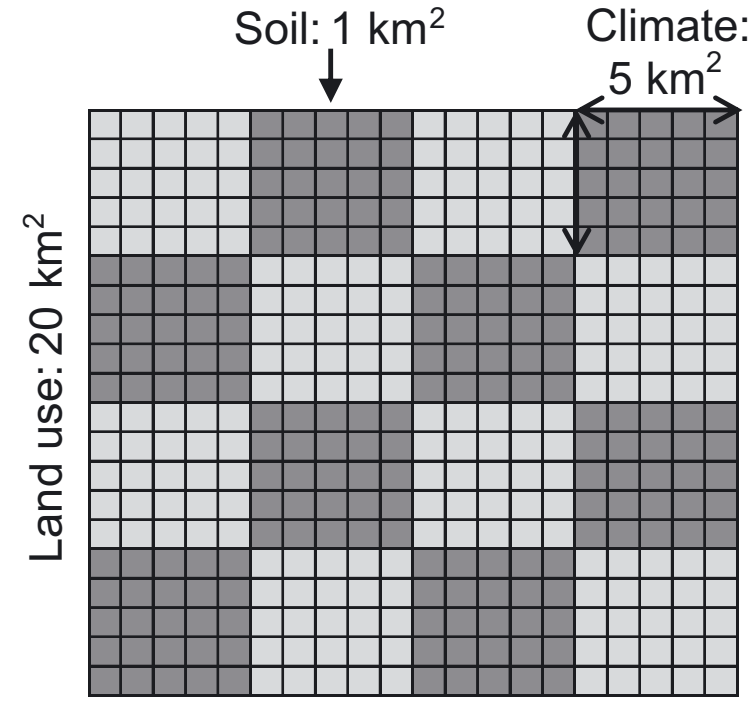

Fig. 1. Resolution of data available to run the Estimation of Carbon in Organic Soils-Sequestration and Emissions (ECOSSE) model at a national scale

Simulations were of 3 types: historical, future and simulations of the potential of mitigation options to reduce soil $\mathrm{C}$ losses. The historical simulations determined changes in soil $\mathrm{C}$ content for each decade since 1950, apportioning the losses to different soil types and changes in land use. These simulations quantified the $\mathrm{C}$ emissions from Scottish soils, and resolved which land-use changes are responsible for the changes in soil $\mathrm{C}$ and on which soil types most changes in soil $\mathrm{C}$ occur. The future simulations quantified the changes in soil $\mathrm{C}$ due to projected land-use and climate change over the next decade. The calculations of the different mitigation options determined which options have the greatest potential to reduce losses of soil C.

The national estimates of changes in soil $\mathrm{C}$ stocks not only determine the total change in soil $\mathrm{C}$, but also apportion the observed change to specific changes in land use, management or climate. This is of crucial importance if we are to implement effective mitigation measures to protect vulnerable soil C sinks (Reay et al. 2007). Bellamy et al. (2005) suggested a possible link to climate change to explain the observed mean loss of soil organic C of $0.6 \% \mathrm{yr}^{-1}$ between 1978 and 2003 in England and Wales. As discussed by Smith et al. (2007b), those findings contradict evidence that UK and European soils as a whole are a net $\mathrm{CO}_{2}$ sink (Janssens et al. 2003), along with data from another long-term study of soil organic C in British woodlands (Kirkby et al. 2005), which suggest a small increase in soil organic matter over $30 \mathrm{yr}\left(0.094 \%\right.$ increase $\left.\mathrm{yr}^{-1}\right)$. Other repeated sampling studies in Europe have shown contrasting results, with some showing loss of soil organic C (in Flemish croplands, Sleutel et al. 2003), attributed to changing manure application practices, and others showing no loss of soil organic C (in Danish croplands, Heidmann et al. 2002, and in Austrian soils, Dersch \& Bohm 1997). Our results provide modelling evidence that will allow the observed $C$ changes in Scottish soils to be attributed to different drivers, and will provide an important contribution to this debate.

\subsection{Input data used to drive the simulations}

Land-use and land-use change data were obtained from the database held by the Centre for Ecology and Hydrology (CEH; Mobbs \& Dyson 2009, Thomson et al. unpubl. data). The spatial distribution of the land-use change data across Scotland is shown in Figs. 8.3 \& 8.4 of Smith et al. (2007a). The decadal changes in land use across Scotland since the 1950s are shown in Fig. 2. The land-use types specified were arable, grassland, forestry and semi-natural (moorland and other uncultivated land). Areas of human settlement and/or infrastructure and water bodies were excluded from the analysis. The data provided included land-use and land-use change data on a $20 \mathrm{~km}^{2}$ grid, specifying historical decadal land-use change for 1950-1959, 1960-1969, 1970-1979, 1980-1989 and 1990-1999, and predicted decadal land-use change for 2000-2009 and

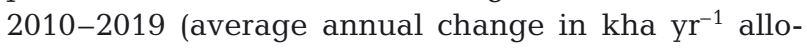
cated in each $20 \mathrm{~km}^{2}$ cell).

Soil data were obtained from the Scottish Soils Knowledge and Information Base (SSKIB; Lilly et al. 2004). This database holds statistical summary data for a set of typical soil horizons for each soil taxonomic unit (series) delineated on the 1:250000 soil map of Scotland. A digitized version of this map comprises around 85000 georeferenced $1 \mathrm{~km}^{2}$ grid cells each with the proportion and name of all the individual soil taxonomic units in that cell. This is further modified by the addition of land use that separates the uncultivated from the cultivated versions (phenotypes) of the same soil taxonomic unit. For the national-scale simulations, the 5 most extensive soils within each cell were used, giving a total of approximately 800 different soil and/or land-use types. This was later combined with climate data to provide a soil wetness class in each $1 \mathrm{~km}^{2}$ cell based on soil and climate parameters (Lilly \& Matthews 1994).

Typical horizon sequences and thicknesses were derived for each of the 800 soil phenotypes in SSKIB, except for those soils where rock normally occurred within $1 \mathrm{~m}$ (e.g. rankers and some upland soils), using information contained within the Scottish Soils Database (Lilly et al. 2004). The distinction between cultivated and uncultivated versions of the same soil series is important because both the soil chemistry and hori- 

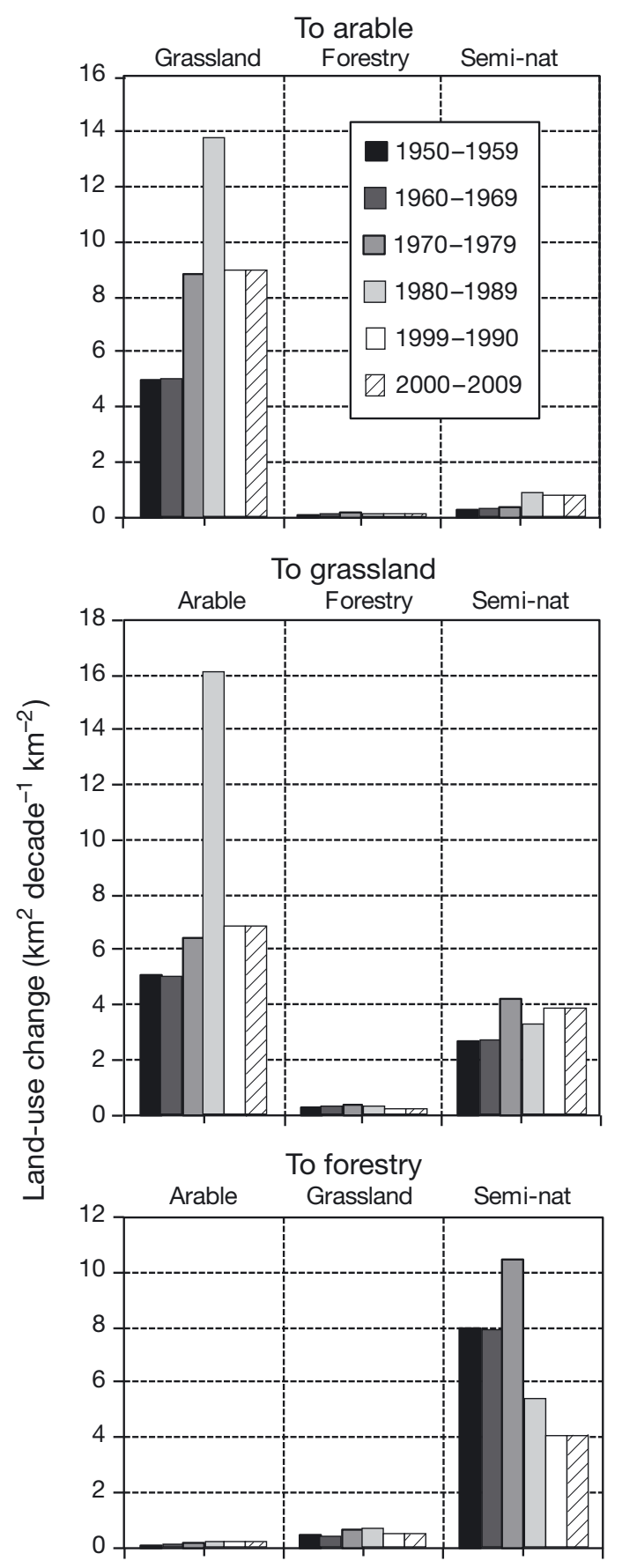

To semi-natural

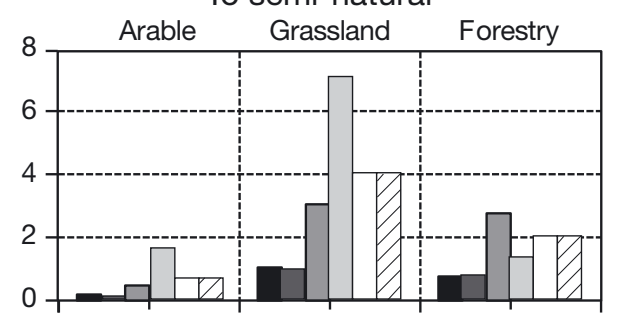

Fig. 2. Decadal changes in land use across Scotland since the 1950s (Mobbs \& Dyson 2009, Thomson et al. unpubl. data) zon sequences differ. Once the typical horizon sequence was determined, summary statistics were derived from the Scottish Soil Analytical Database (Lilly et al. 2004). Only soil horizons that matched those selected as being typical for that soil were used in the derivation of the summary statistics.

Data for cultivated soils were then subdivided into 2 land-use groups, arable and grassland, and, for uncultivated soils, into forestry and semi-natural land covers. Rough grassland is included in the seminatural category. This was achieved using correction factors derived from the Scottish Soils Analytical Database (Lilly et al. 2004). Because the summary statistics for cultivated soils includes data from soils with arable, grassland and rotational grassland land uses, correction factors were applied in order to estimate $\mathrm{C}$ and $\mathrm{pH}$ values for the arable and grassland subgroups. These correction factors were derived from over 2000 individual measurements of topsoil C and $\mathrm{pH}$. In total, $0.2 \%$ was subtracted from all SSKIB cultivated topsoil mean $\mathrm{C}$ values to derive a value for arable soils, whereas $1.2 \%$ was added to derive a value for $\mathrm{C}$ contents of grassland soils. For $\mathrm{pH}$, arable topsoils were increased by $0.04 \mathrm{pH}$ units, whereas grassland topsoils were decreased by 0.46 (Smith et al. 2009). These values were used to initialize the soil $\mathrm{C}$ pools under grass and arable land uses, thus defining the activity of the SOM and the plant inputs as described by Smith et al. (2010b, Section 2.4).

There were only small differences in the organic C contents of organic layers under forestry compared to semi-natural soils, with some horizons having greater organic C contents in afforested compared with semi-natural soils, and other horizons showing the opposite trend (Smith et al. 2010b). Therefore, no adjustment was made to the $\mathrm{C}$ contents of the soil horizons of uncultivated soils to distinguish between afforested soils and those under semi-natural vegetation. However, it was assumed that soils under forestry were more likely to develop a deeper litter layer than those under semi-natural grasslands or moorland. The litter layer under forestry was determined from measurements. The average thickness of the partially decomposed organic debris (LF) horizon under forestry was determined along with the average $\mathrm{C}$ content and its standard deviation. This horizon was added to all uncultivated soil profiles to derive data for soils under forestry. The bulk density of the LF horizon was averaged from a number of measured LF horizons, whereas the bulk densities of the other soil horizons from both cultivated and uncultivated soils were derived by a series of pedotransfer functions. These pedotransfer functions are simple regression equations that relate the dry bulk 
density of a soil horizon to the organic $\mathrm{C}$ and clay and/or silt contents and that were developed from data from a wide range of Scottish soils (Lilly 1999, 2000). Following the approach taken by King \& Franzmeier (1981) and the Hydrology of Soil Types classification (Boorman et al. 1995), the soil horizons were grouped into topsoils and subsoils and according to the mode of deposition of the soil parent material. The soil characteristic summary data provided for each horizon and land-use type (arable, grassland, forestry and semi-natural) included the top and bottom depths of the horizon $(\mathrm{cm})$, the $\mathrm{C}$ content (kt $20 \mathrm{~km}^{-2}$ ), $\mathrm{pH}$, percent clay, silt and sand, and the estimated bulk density $\left(\mathrm{g} \mathrm{cm}^{-3}\right)$.

The characteristics of each horizon in the soil series identified in each grid cell were used to drive the model. Total soil C $\left(\mathrm{kg} \mathrm{C} \mathrm{ha}^{-1}\right)$ was used to determine the organic inputs to the soil and the amount of $\mathrm{C}$ in each of the SOM pools at the start of the simulation, as described by Smith et al. (2010b, Section 2.4). This was done for soils defined under each land use identified in the cell, thus allowing the impact of land-use change on SOM turnover to be simulated by changing the organic inputs from those estimated for the original land use to the values obtained for the new land use. Soil $\mathrm{pH}$ was used to calculate rate-modifying factors for aerobic and anaerobic decomposition and to determine the stable $\mathrm{C}: \mathrm{N}$ ratio. The percent clay was used to calculate the proportion of SOM retained in the soil on decomposition following the approach of Coleman \& Jenkinson (1996) and, together with bulk density $\left(\mathrm{g} \mathrm{cm}^{-3}\right)$ and silt content, to estimate the water content at field capacity, using the equation provided by Hall et al. (1977). This equation was originally derived to determine field capacity in soils from England and Wales, and thus will introduce some error when applied to Scottish soils, especially peats. However, because the activity of the SOM decomposition is initialized using the specified soil conditions, the impact of errors in estimated field capacity on changes in soil $\mathrm{C}$ will be small. If the focus of the simulations was the impact of changes in the soil water status on soil $\mathrm{C}$, a more appropriate pedotransfer function would be required.

The moisture and temperature rate modifiers were calculated using weather data. The historical simulations use monthly long-term average data. Data were downloaded as a grid of $5 \mathrm{~km}^{2}$ from the climate monitoring service of the MetOffice UK (http:// www.ukcip.org.uk/index.php?id=161\&option= $\mathrm{com}_{-}$ content\&task=view).

Monthly long-term average data are based on the period 1961-1990. Future weather data were ob- tained from the UKCIP02 database (UKCIP 2002). UKCIP02 data were used in preference to the more recent UKCP09 because gridded spatial data were not available for UKCP09 at the time of the present study. The UKCIP02 data are derived from the HadCM3 model for 4 scenarios based on the predicted cumulative $\mathrm{CO}_{2}$ emissions between 1990 and 2100, as shown in Table 1 . The data include rainfall and temperature predictions for each scenario for 3 future time steps: 2020, 2050 and 2080. These data are in $5 \mathrm{~km}^{2}$ grids covering the whole of Scotland.

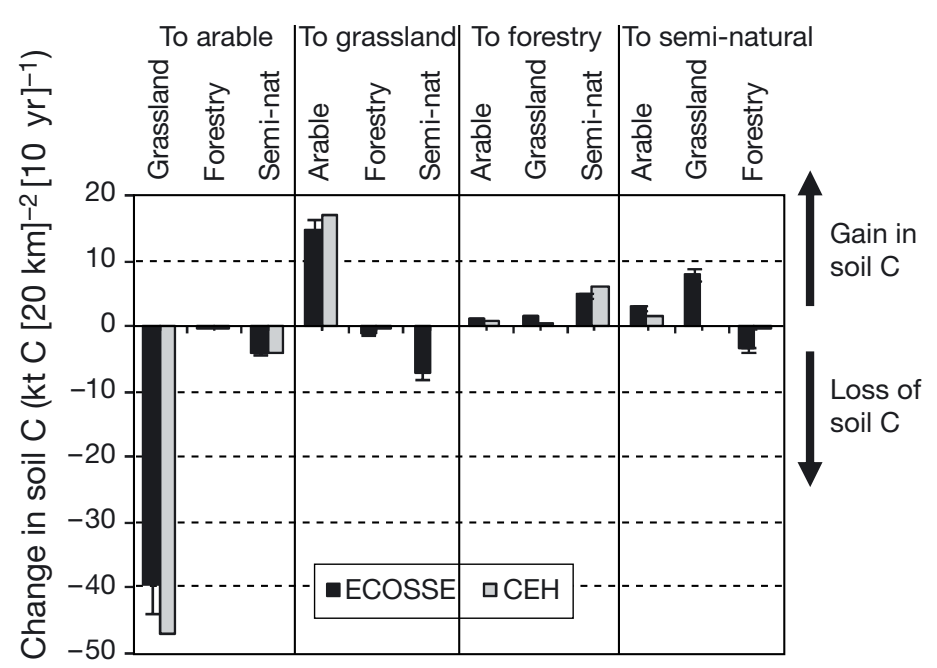

Fig. 3. Comparison of simulated changes in soil C content from 2000 to 2009 divided according to land-use change as estimated by ECOSSE and by the Centre for Ecology and Hydrology (CEH). Values are averaged across Scotland. Error bars indicate the uncertainty in the simulations calculated in Smith et al. (2010b) from the simulation of the National Soil Inventory of Scotland (NSIS) sites as the average deviation of the simulations from measurements (root mean squared deviation $=11 \%$ ). Note the units used for change in soil $\mathrm{C}$ reflect the $20 \mathrm{~km}^{2}$ grid cells and the decadal time slice used in the land-use change data 


\section{RESULTS}

\subsection{Change in soil $\mathrm{C}$ associated with different land-use changes}

A comparison of the average changes in soil C content across Scotland as estimated by ECOSSE and by the CEH GHG inventory (Milne et al. 2004, summarised in Smith et al. 2007a, 2009) is shown for 2000-2009 in Fig. 3. The CEH approach estimates the change in soil $\mathrm{C}$ with change between 2 land uses from the equilibrium soil $\mathrm{C}$ content under the initial land use, the equilibrium soil $\mathrm{C}$ content under the final land use and a time constant for the change. The ECOSSE simulations use the SSKIB soil data and historical weather, land-use and land-use change data as described in Section 2.2. The results show the changes in soil C content calculated using a simulation started with 1950. Changes in soil C stocks due to land-use change occurring between 1950 and the end of the respective decade contribute to the changes in soil C stocks estimated in the given decade; for example, land-use changes occurring between 1950 and 2009 contribute to the changes in soil $\mathrm{C}$ stocks estimated during the decade 2000-2009. The effects on soil C of any land-use change that occurred before 1950 will be omitted from the results, but the effect of land-use change on soil $\mathrm{C}$ diminishes with time, so this is not anticipated to introduce a large error in the national estimates.

The correlation between the ECOSSE and CEH estimates is highly significant $\left(r^{2}=0.93, p<0.001\right.$; Smith \& Smith 2007). A $t$-test also indicates that the mean values estimated by the 2 approaches are not significantly different, indicating that the 2 sets of estimates show similar trends. On average, the ECOSSE simulated results differ from the CEH estimates by $-0.2 \mathrm{kt} C 20$ $\mathrm{km}^{-2} 10 \mathrm{yr}^{-1}$, which is equivalent to a bias of $-3 \%$ of the average size of change in soil $\mathrm{C}$ estimated by $\mathrm{CEH}$ (note the units used here reflect the $20 \mathrm{~km}^{2}$ land-use change grid and the decadal time slice of land-use changes). This provides confidence in the simulations because these 2 very different approaches provide broadly similar results. The results do, however, differ in the detail, as evidenced by the average size of the absolute difference between the CEH and ECOSSE estimates, which is $2.9 \mathrm{kt} \mathrm{C} 20 \mathrm{~km}^{-2} 10 \mathrm{yr}^{-1}$, equivalent to $45 \%$ of the average size of change in soil $\mathrm{C}$ estimated by $\mathrm{CEH}$.

Most land-use changes produce changes in soil C estimated by the 2 methods that are of a similar magnitude and sign. The ECOSSE simulations of changes in soil $\mathrm{C}$ due to land-use change from semi-natural to grassland show a larger loss of soil $\mathrm{C}$ than estimated by the CEH method. Similarly, ECOSSE simulates a larger gain in soil $\mathrm{C}$ due to land-use change from grassland to semi-natural. Correspondingly, ECOSSE estimates a larger loss of soil $\mathrm{C}$ due to land-use change from forestry to semi-natural and a smaller gain in soil $\mathrm{C}$ for the land-use change from semi-natural to forestry. If these results were to be omitted from the analysis, the average size of the difference between the CEH and ECOSSE results would be reduced to $19 \%$ of the average size of change in soil $\mathrm{C}$ estimated by $\mathrm{CEH}$. These differences occur due to processes that are included in ECOSSE associated with soil disturbance and reduced plant inputs when vegetation is immature, as described by Smith et al. (2010b, Section 2.5).

The greatest simulated losses in soil $\mathrm{C}$ are due to land-use change from grassland to arable, and the greatest simulated sequestration of $\mathrm{C}$ occurs due to land-use change from arable to grassland (Fig. 3). This result is consistent with the results reported by $\mathrm{CEH}$ (Milne et al. 2004) and Falloon et al. (2006). The distribution of changes in soil C simulated across Scotland for 2000-2009 due to all land-use change, conversion of grassland to arable and conversion of arable to grassland are shown in Fig. 4. The maps illustrate that the greatest losses due to conversion of grassland to arable occur in the east and south. Similarly, the greatest gains due to conversion of arable to grassland occur on the east coast. When the effects of all land-use changes are taken together, the losses of soil $\mathrm{C}$ outweigh the gains, resulting in a simulated change in soil $\mathrm{C}$ of $-810 \pm 89 \mathrm{kt} \mathrm{yr}^{-1}$ across Scotland. Given a total C stock in the top $100 \mathrm{~cm}$ of Scottish soils of $2187 \times 10^{3} \mathrm{kt}$ (Bradley et al. 2005), this is equivalent to a loss of soil C of $0.037 \pm 0.004 \% \mathrm{yr}^{-1}$ between 2000 and 2009 .

\subsection{Changes in soil $\mathrm{C}$ on different soil types}

The ECOSSE simulated changes in soil C since 1950 across Scotland for C-rich soils and non-C-rich mineral soils are shown in Fig. 5. C-rich soils are defined here as soils with a $\mathrm{C}$ content of $>6 \%$. This value for the $\mathrm{C}$ content of C-rich soils was selected following Smith et al. (2007a), but could equally have been set at another level if required. Between 2000 and 2009, losses from C-rich soils represent $64 \%$ of the total losses. Across Scotland, the simulated change in soil C on C-rich soils between 1950 and 2009 is $-62.5 \mathrm{Mt}$, compared with $-35.4 \mathrm{Mt}$ on non-C-rich mineral soils. The distribution in the simulated changes in soil C stocks in C-rich soils is shown from 1950 to 2019 in Fig. 6. Note the high losses of C from C-rich soils up to 1980, when the losses decline as plant communities from the earlier land-use changes reach maturity. The losses between 2000 and 2009 from C-rich soils and non-C-rich mineral soils associated with different land-use changes are shown 

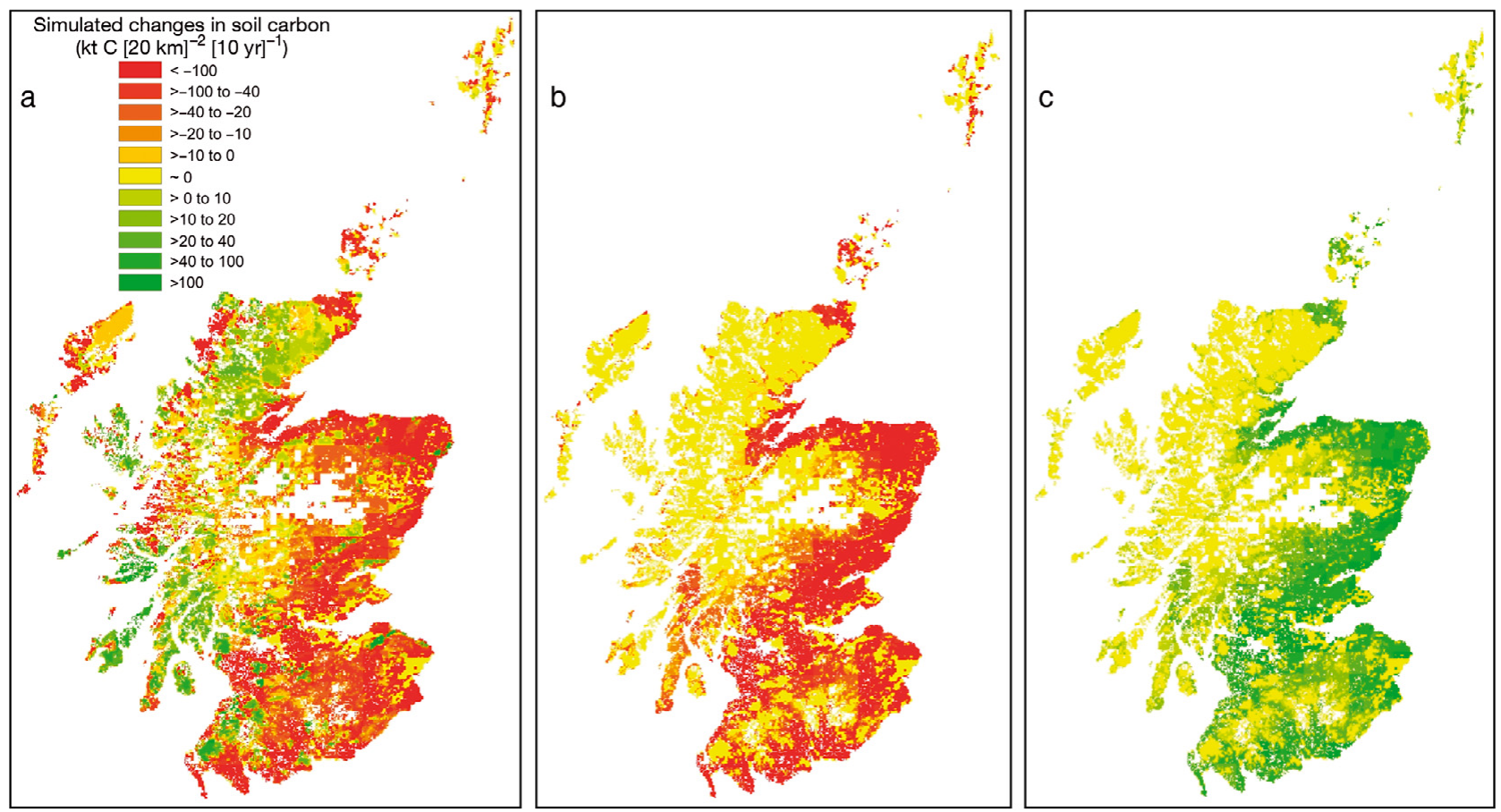

Fig. 4. Simulated change in soil C stocks due to all land-use changes occurring in Scotland 2000-2009. Change due to (a) all landuse changes, (b) conversion of grassland to arable and (c) conversion of arable to grassland. White areas: no land-use change

in Fig. 7. The results represent the emissions that occur between 2000 and 2009, but show the impact of landuse changes occurring between 1950 and 2009. The largest losses in soil $\mathrm{C}$ are associated with the conversion of non-C-rich mineral soil from grassland to arable, while the largest gains in soil $\mathrm{C}$ are associated with the conversion of non-C-rich mineral soil from arable to grassland. This reflects the higher proportion of these land-use changes occurring on non-C-rich mineral soils. Other large losses in soil $\mathrm{C}$ are observed due to conversion of C-rich soils from grassland to arable, and from semi-natural to grassland. Whereas the changes in soil $\mathrm{C}$ in non-C-rich mineral soils are largely compensatory (i.e. changes in soil $\mathrm{C}$ associated with one land-use change compensate for the changes in soil $\mathrm{C}$ associated with another), the changes in Crich soils are not, resulting in an average loss of soil C from C-rich soils of $19 \mathrm{kt} 20 \mathrm{~km}^{-2} 10 \mathrm{yr}^{-1}$, compared with an average loss from non-C-rich mineral soils of

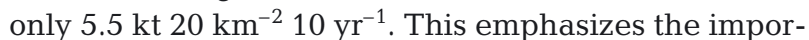
tance of C-rich soils in any national estimates of GHG emissions. These results suggest that mitigation options to reduce losses of soil $\mathrm{C}$ might recommend different policies for land-use change on non-C-rich mineral and C-rich soils.

A gain in soil $\mathrm{C}$ is simulated due to the land-use change from semi-natural to forestry on C-rich soils (Fig. 7). However, this result may be an artifact of the approach used to derive the soil $\mathrm{C}$ contents used to drive the model for afforested and semi-natural soils as described in Section 2.2, and so the results presented should be treated with caution. Because there was insufficient experimental evidence to differentiate the typical characteristics of soils under forestry or seminatural land use, the typical soil parameters for uncul-
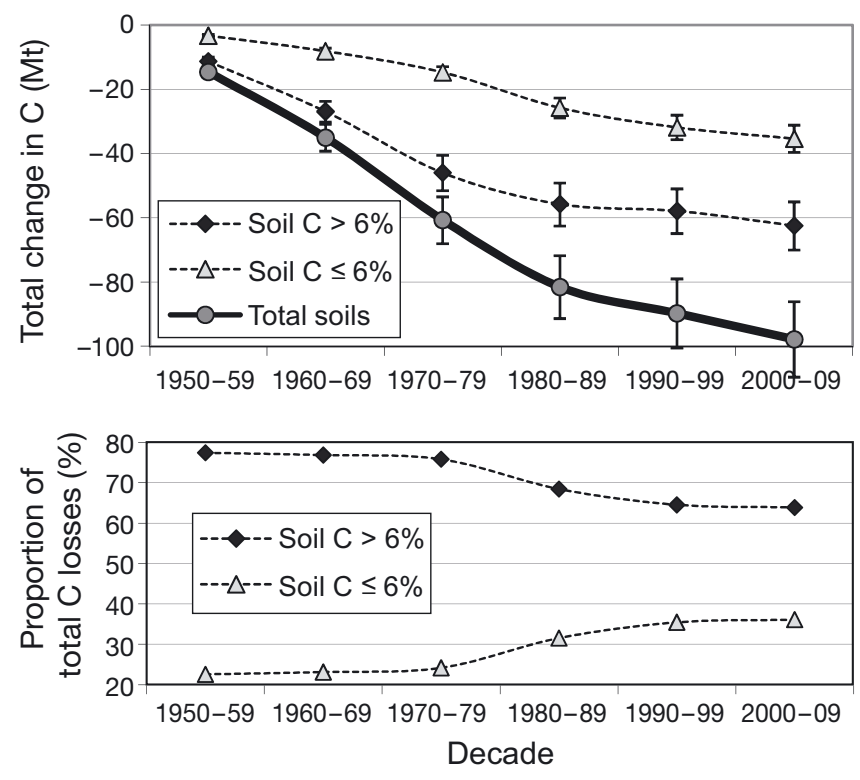

Fig. 5. Simulated total changes in C stocks across Scotland from 1950 to 2009 for different soil types as simulated by ECOSSE, assuming soil disturbance on afforestation 

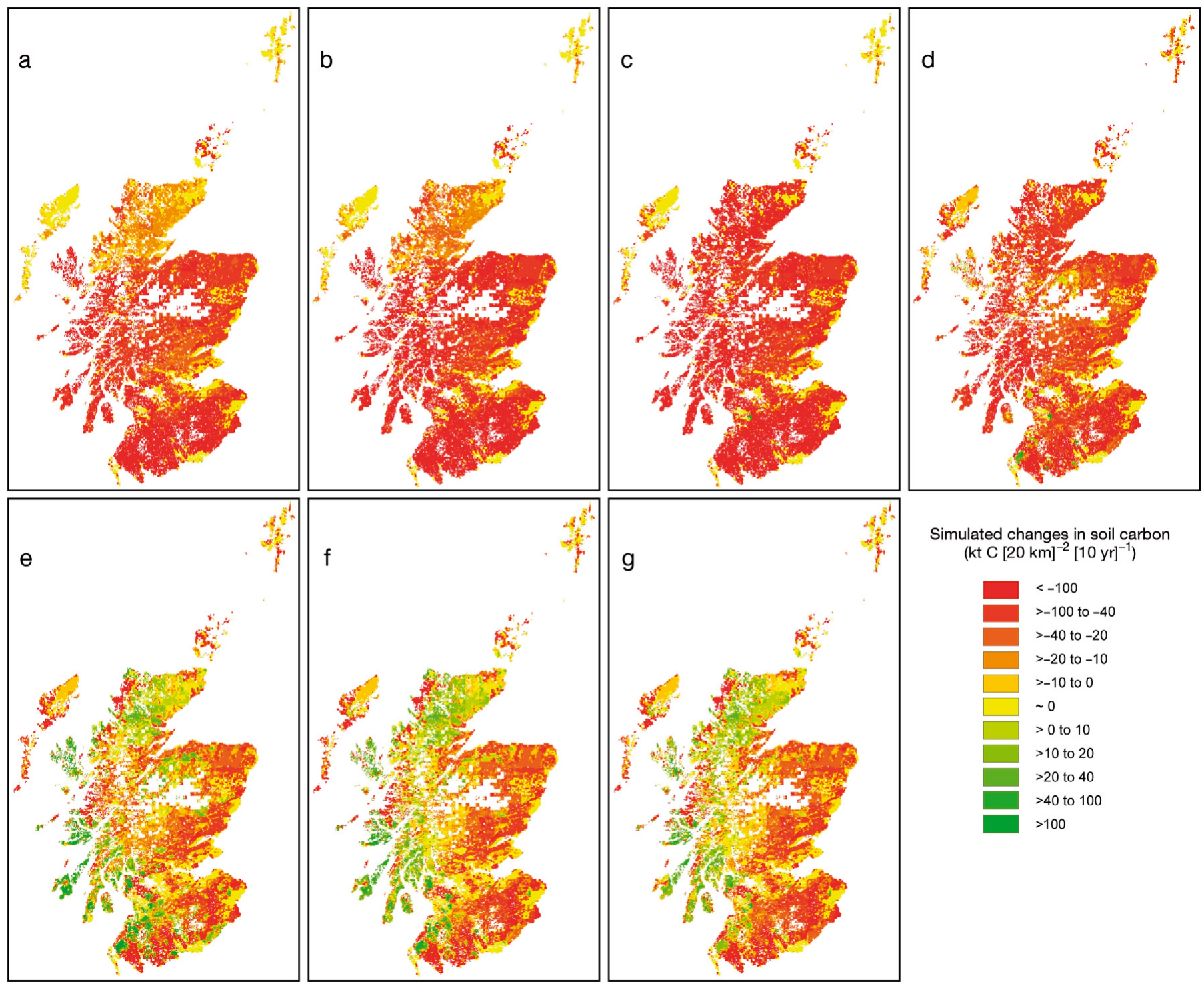

Simulated changes in soil carbon $\left(\mathrm{kt} \mathrm{C}[20 \mathrm{~km}]^{-2}[10 \mathrm{yr}]^{-1}\right)$

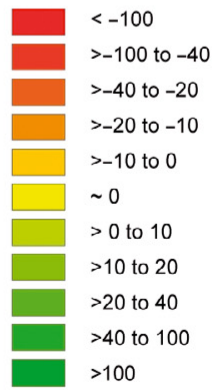

Fig. 6. ECOSSE simulations of changes in soil C stocks on C-rich soils ( $>6 \%$ soil C) across Scotland due to all land-use changes occurring between 1950 and 2010. Simulations assume soil disturbance on afforestation in the (a) 1950s, (b) 1960s, (c) 1970s, (d) 1980s,

(e) 1990s, (f) 2000s and (g) 2010s

tivated soil types were used for soil horizons under both forestry and semi-natural land use. This neglects any impact of drainage of saturated semi-natural soils prior to afforestation. Increased respiration and release of $\mathrm{CO}_{2}$ has been observed on draining peats in both laboratory and field experiments (Freeman et al. 1993, Moore \& Dalva 1993, Funk et al. 1994, Martikainen et al. 1995). Data on litter layers were added to the surface of the forested soils, resulting in a profile that holds more total $\mathrm{C}$ than the semi-natural soil. Therefore, despite initial losses in soil $\mathrm{C}$ due to soil disturbance and reduced plant inputs on land-use change, over the long term, the land-use change from seminatural to forestry will result in an apparent gain in soil
C. This result may or may not be correct, and more data on the $\mathrm{C}$ contents of forested soils are needed to confirm this result.

\subsection{Predicted changes in soil $\mathrm{C}$ due to projected land-use and climate change over the next decade}

The predicted changes in soil $\mathrm{C}$ due to projected land-use and climate change over the next decade are very similar to the changes simulated for 2000-2009. The overall trend is towards increased emissions, with

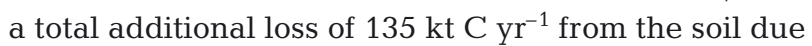
to the projected scenarios of land-use change in Scot- 


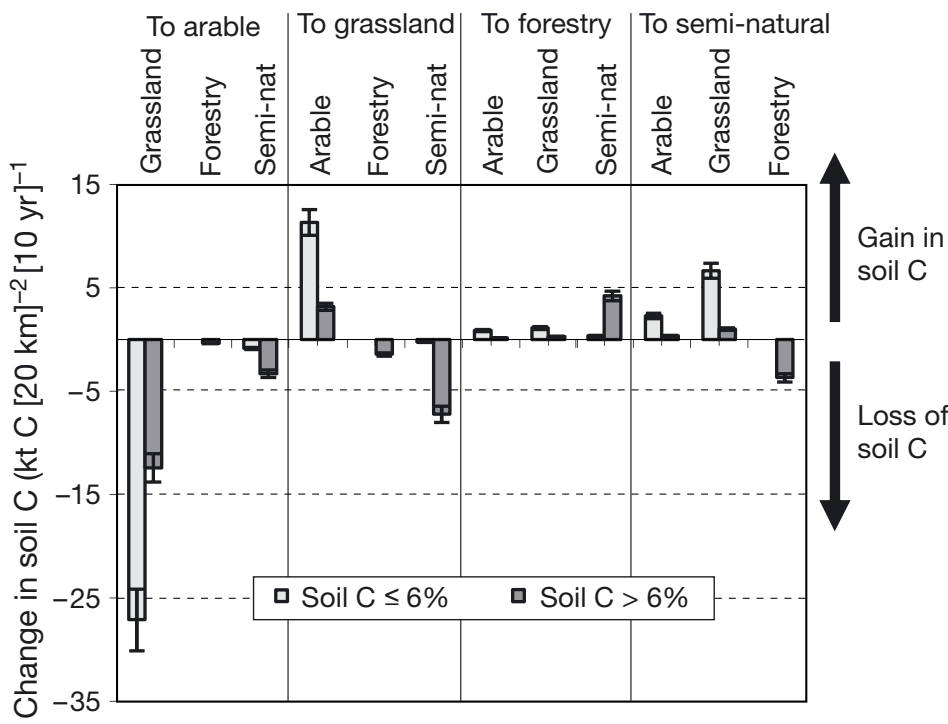

Fig. 7. Comparison of simulated changes in soil C content from 2000 to 2009 divided according to land-use change on organic and mineral soils as estimated by ECOSSE. Values are averaged across Scotland. Error bars indicate the uncertainty in the simulations calculated from the simulation of the National Soil Inventory of Scotland (NSIS) sites as the average deviation of the simulations from measurements (root mean squared deviation $=11 \%$ ). Note the units used for change in soil C reflect the $20 \mathrm{~km}^{2}$ grid cells and the decadal time slice used in the land-use change data

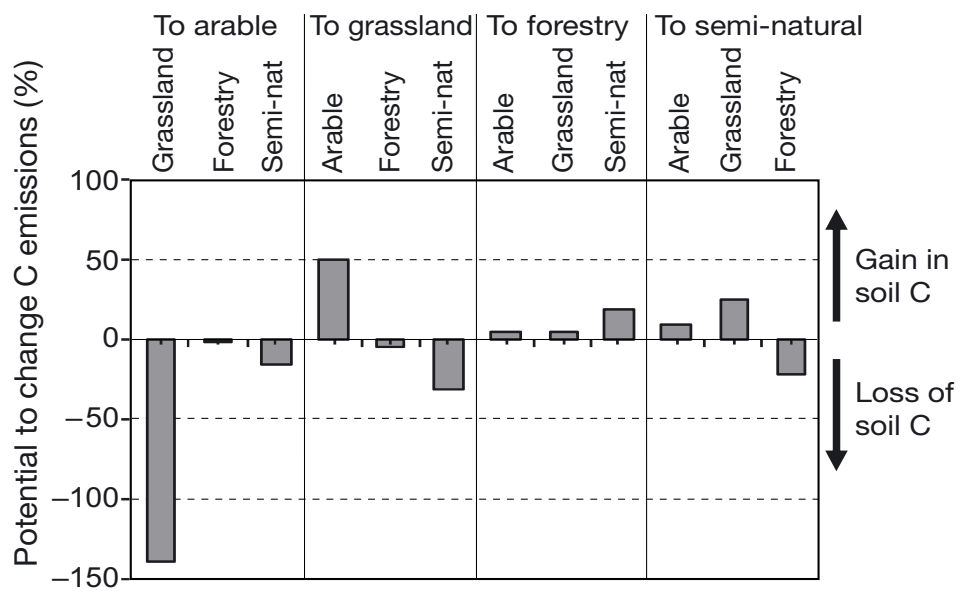

Fig. 8. The impact of land-use change on the total $\mathrm{C}$ emissions of Scotland over the next decade as estimated by ECOSSE

land. This is equivalent to a total projected loss of soil $\mathrm{C}$ of $0.043 \pm 0.005 \% \mathrm{yr}^{-1}$ between 2010 and 2019 .

\subsection{Mitigation options to reduce losses of soil C}

Fig. 8 shows the potential of each land-use change to affect the $\mathrm{C}$ emissions of Scotland. The potential to affect $\mathrm{C}$ emissions is calculated from the simulated change in total $\mathrm{C}$ emissions that occur when the given land-use change is reduced to zero, and thus accounts for both the area of predicted land-use change and the size of the impact of the land-use change on soil C stocks.

Reducing land-use change from grassland to arable has the greatest potential to reduce soil C losses. If the area of land converted from grassland to arable was reduced to $28 \%$ of its present rate of conversion, the soil C losses across Scotland would be reduced to zero. In other words, if, in a given grid square, the conversion of arable to grassland from 2010 to 2019 was 100 ha, reducing the area of land converted from arable to grassland to 28 ha would reduce the losses of soil $\mathrm{C}$ such that the net losses of soil $\mathrm{C}$ across Scotland would be zero. However, given the current agricultural market, such a mitigation option may be unrealistic.

Other significant losses of soil C occur due to the conversion of semi-natural land to arable or grassland. The results suggest that if policies were designed to reduce conversion of seminatural land to arable or grassland, net losses of soil $\mathrm{C}$ could be reduced to $53 \%$ of the present emissions. If this were coupled with an increase in the conversion of grassland to semi-natural land by $125 \%$ of the present rate of conversion (i.e. increase 100 ha conversion of grassland to semi-natural to 225 ha), net losses of soil C would be reduced to zero. Alternatively, a $63 \%$ increase in the present rate of conversion of arable to grassland (i.e. increase 100 ha conversion of arable to grassland to $163 \mathrm{ha}$ ) would also result in zero net losses of soil $\mathrm{C}$ when coupled with the reduced conversion of semi-natural land to arable or grassland. This could equally be achieved by decreasing the current rate of conversion of grassland to arable to $77 \%$ of its present rate (i.e. decrease 100 ha conversion of grassland to arable to $77 \mathrm{ha}$ ).

The results also suggest that conversion of semi-natural land to forestry would sequester additional soil C. However, the national soils data used to drive the model does not presently account for the detail of changes in soil C likely to occur due to drainage and disturbance of semi-natural soils following afforestation. Therefore, in the present study, conversion of semi-natural land to forestry was not included as a potential method to sequester soil C. Further work on the $\mathrm{C}$ content of forested soils and the changes occurring in soil $\mathrm{C}$ on afforestation is urgently needed.

Similarly, the results suggest that conversion of forestry to semi-natural land results in a loss of soil C, and so this land-use change should be reduced. While a short-term loss of soil $\mathrm{C}$ is consistent with a reduction 

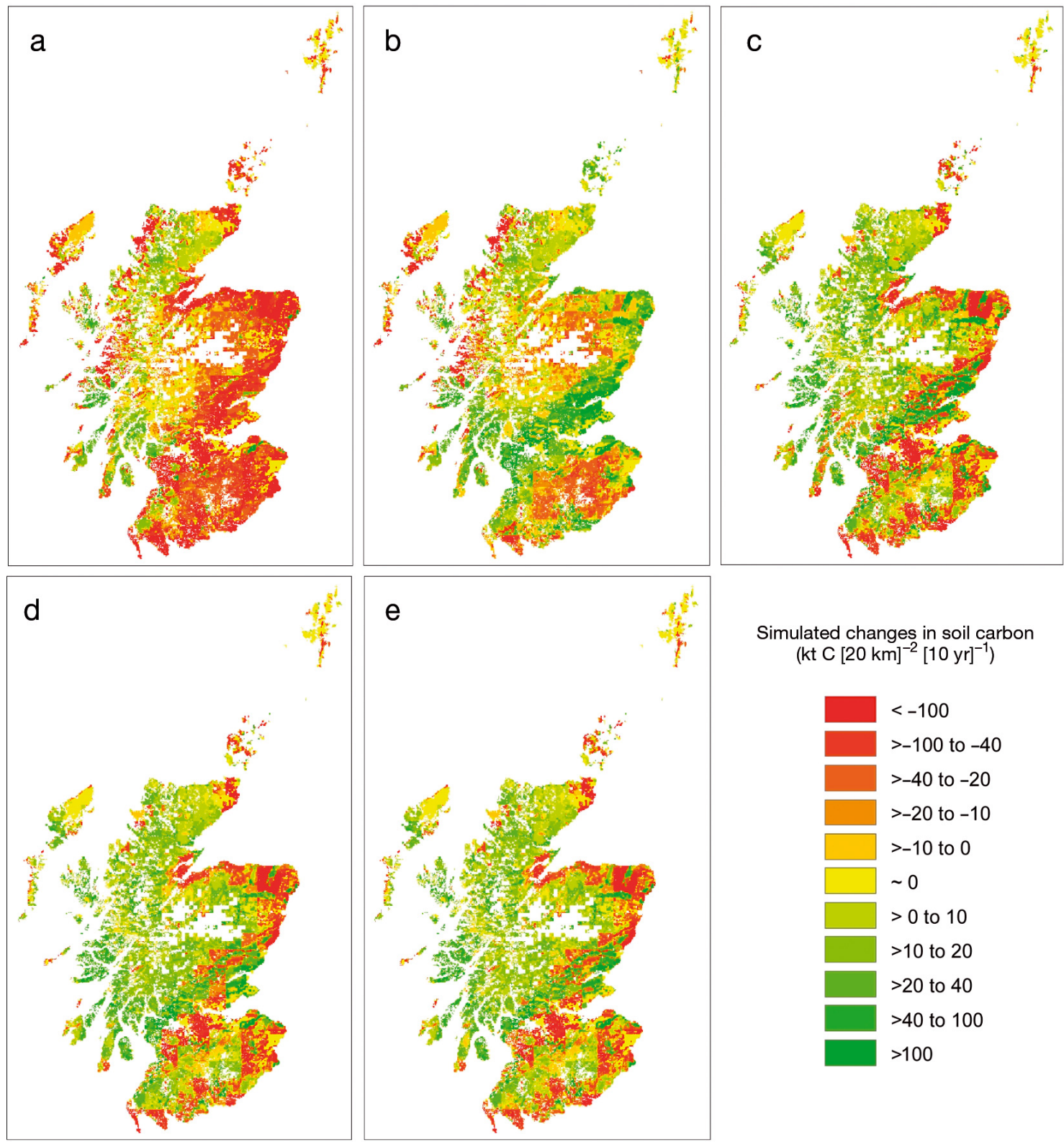

Fig. 9. Simulated changes in soil C stocks in 2010 to 2019 as predicted by ECOSSE. (a) No mitigation options applied; (b) rate of conversion of grassland to arable decreased to $28 \%$ of the present rate; (c) conversion of semi-natural land to arable or grassland stopped and conversion of grassland to semi-natural increased by $125 \%$ of the present rate; (d) conversion of semi-natural land to arable or grassland stopped and conversion of arable to grassland increased by $63 \%$ of the present rate; and (e) conversion of semi-natural land to arable or grassland stopped and conversion of grassland to arable decreased to $77 \%$ of the present rate

in soil C on disturbance of the soil, as discussed in the previous sections, this result could be an artifact of the method used to derive the data for afforested and semi-natural soils. No account is taken of the impact of possible changes in soil hydrology if drains are blocked on restoration of the land to its semi-natural state. Therefore, this result should not be used to suggest reduced conversion of forestry to semi-natural land as a mitigation measure. Again, further work is urgently needed on the $\mathrm{C}$ content of afforested soils and the changes in soil $\mathrm{C}$ occurring on conversion of forested to semi-natural land.

These results suggest at least 4 mitigation options that would be effective tools for achieving zero net losses of C from Scottish soils: (1) reduce the predicted rate of conversion of grassland to arable to $28 \%$ of the present rate, or stop conversion of semi-natural land to arable or grassland and either (2) increase the conver- 
sion of grassland to semi-natural land by $125 \%$ of the present rate, (3) increase the conversion of arable to grassland by $63 \%$ of the present rate or (4) reduce the conversion of grassland to arable land to $77 \%$ of the present rate.

The mitigation options were applied as a multiplication factor to the predicted land-use changes for 2010-2019. The impacts on the distribution of changes in soil C stocks of applying these mitigation options are shown in Fig. 9. Reducing conversion of grassland to arable land results in a reduction in the loss of soil $\mathrm{C}$ across the east coast and central belt of Scotland, whereas the losses on the west coast remain relatively unchanged. Stopping conversion of semi-natural land to arable or grassland and either increasing conversion of grassland to semi-natural or arable to grassland, or reducing conversion of grassland to arable land, all result in reduced loss of soil $\mathrm{C}$ across the west coast and smaller reductions on the east coast and central belt. These mitigation options represent simple changes to the amount of land-use change occurring. More subtle changes in land use, such as changes in the distribution of crops, management of forestry and grazing of animals, could be applied in a similar way through modification of the land-use types selected.

\section{IMPLICATIONS FOR UPLAND ORGANIC SOILS}

The ECOSSE model has been applied to provide national simulations of soil $\mathrm{C}$ turnover in organic as well as mineral soils from principles established in existing models. These models were originally developed on mineral soils but, by adding descriptions of processes and impacts that are important in organic soils, the same model can be used to simulate a wider range of soil types. This is an important facility, because under the influence of land-use and climate change, upland organic soils may become more aerobic, thus changing their basic functioning. In order to design approaches to manage such changes, it is necessary to simulate the transition states of soils undergoing land-use and climate change.

The land uses that dominate in upland organic soils are forestry and extensive grazing of semi-natural vegetation (Mobbs \& Dyson 2009). However, there are insufficient data available in the SSKIB database to determine typical horizon sequences for soils under forestry and to determine their $\mathrm{C}$ contents. Statistical analysis of the data suggests that the $C$ contents of soil horizons in uncultivated soils provide a good estimate of soil C contents of both forested and seminatural soils, while higher inputs of more recalcitrant plant material (Coleman et al. 1997) lead to a deeper litter layer under forestry. This approach leads to a higher total $\mathrm{C}$ content in the soil profile and litter layer of forested soils compared to semi-natural soils. However, in upland organic soils, this may not be the case.

Upland organic soils under semi-natural land use tend to be highly saturated and often require drainage during preparation for afforestation, potentially leading to large losses of soil $\mathrm{C}$ due to an increased rate of aerobic decomposition following drainage (Freeman et al. 1993, Moore \& Dalva 1993, Funk et al. 1994, Martikainen et al. 1995). Experimental evidence into the changes in soil $\mathrm{C}$ contents following afforestation can be contradictory and highly site specific. Further detailed research is urgently needed to provide data on soil C contents for semi-natural and forested soils, particularly in upland areas.

If the forested soil $\mathrm{C}$ had been overestimated in upland organic soils compared to semi-natural soils, the simulations would tend towards a steady state with a greater soil $\mathrm{C}$ content under forestry than under semi-natural land use. This would then suggest that, in the long-term, the conversion of semi-natural land to forestry would sequester more soil $C_{i}$ if the semi-natural land use was a saturated highly organic soil, this is unlikely to be the correct result as large losses of soil C are likely to occur on drainage. An alternative simulation approach combines a dynamic model of changes in forest biomass stocks to generate soil inputs with a description of initial losses due to soil disturbance (Hargreaves et al. 2003). However, inaccuracy in the estimation of plant inputs and incomplete knowledge of the soil conditions at a national scale is likely to result in greater errors than are introduced through the use of the soil $\mathrm{C}$ data to initialize the model.

Land-use changes, such as from semi-natural to forestry - which is a change from a long-term uncultivated land use to a land use with slowly establishing vegetation - result in losses of soil $\mathrm{C}$ due to soil disturbance and reduced plant inputs when the new vegetation is immature. The parameters describing release of physically protected SOM on soil disturbance and reduced plant inputs are currently set according to the normal forestry practices used in the UK. If forestry practices were to move to minimal soil disturbance, these parameter values might change, resulting in a smaller release of soil $\mathrm{C}$ on afforestation of long-term uncultivated soil than is currently assumed, and a smaller short-term loss associated with afforestation. Differentiation of management practices used in upland and lowland sites might further improve the accuracy of the simulated impacts of soil disturbance and reduced plant inputs following afforestation. Research into the physical protection of SOM in organic soils and the release of SOM following different types of soil disturbance is needed to inform parameteriza- 
tion of the model and to design forestry practices to reduce $\mathrm{C}$ losses.

Across Scotland, the simulated change in soil $\mathrm{C}$ from C-rich soils between 1950 and 2009 is -62.5 Mt, compared with $-35.4 \mathrm{Mt}$ from non-C-rich mineral soils; losses from C-rich soils between 2000 and 2009 comprise $64 \%$ of the total soil C losses. This emphasizes the importance of $\mathrm{C}$-rich soils in any national estimates of GHG emissions, and the need to avoid land-use changes that result in $\mathrm{C}$ losses on these soils. These results also suggest that mitigation options to reduce losses of soil $\mathrm{C}$ might recommend different policies for land-use change on non-C-rich mineral soils versus C-rich soils.

One mitigation option that could be used in upland soils to achieve zero net loss of $\mathrm{C}$ from Scottish soils is to stop conversion of semi-natural land to managed grassland and increase conversion of managed grassland to semi-natural land by $125 \%$ of the present rate. Possible ways of encouraging practices to reduce soil$\mathrm{C}$ losses from the agricultural sector may come about through improving implementation of existing good agricultural and environmental condition (GAEC) standards for soil protection by strengthening rural development policy. In Scotland, this could be through the Scotland Rural Development Programme (Scottish Government 2010), redesign of the European Union Common Agricultural Policy to encourage the maintenance of existing C stocks (Smith et al. 2007c), or voluntary C markets for improved C sequestration in soils (Stern 2007, Blyth et al. 2009). Reducing land-use change on upland organic soils is likely to encourage a compensatory increase in land-use change on nonC-rich mineral soils to meet the demands of the market. Without a change in consumer demand, these potential mitigation options represent an oversimplified view of reality. More realistic mitigation options should be derived by coupling these simulations to an economic analysis of the response of the market to changes in supply.

Another mitigation option that could be used on highly organic soils in Scotland is peatland restoration. Estimates of the area and severity of peatland degradation vary and estimates of the mitigation potential of restoration are also uncertain, but the International Union for the Conservation of Nature has proposed that Scotland could increase $\mathrm{C}$ stocks by $2.76 \mathrm{Mt} \mathrm{CO}_{2}$ equiv. $\mathrm{yr}^{-1}$, assuming a, possibly optimistic, accrual rate of $4.6 \mathrm{t} \mathrm{CO}_{2}$ equiv. $\mathrm{yr}^{-1}$ (Byrne et al. 2004) and the biodiversity target of 600000 ha restoration by 2015 (IUCN UK Committee Peatland Programme 2010). Models such as ECOSSE could have a significant role in better quantifying the potential of these mitigation targets, and in reducing the uncertainty associated with the estimates.
Acknowledgements. This work was funded by the Rural and Environment Research and Analysis Directorate of the Scottish Government, Science Policy and Co-ordination Division. P.S. is a Royal Society-Wolfson Research Merit Award holder. Rothamsted Research is an institute of the Biological and Biological Sciences Research Council; A.W. and K.C. acknowledge support from the Institute Strategic Programme Grants on Bioenergy and Climate Change and the Cross Institute Programme on Sustainable Soil Function (SoilCIP). P.F. was supported by the Joint DECC and Defra Integrated Climate Programme - DECC/Defra (GA01101) and the EU Sixth Framework Programme (Global Change and Ecosystems subprogramme) project CarboNorth (project no. 036993).

\section{LITERATURE CITED}

Bellamy PH, Loveland PJ, Bradley RI, Lark RM, Kirk GJD (2005) Carbon losses from all soils across England and Wales 1978-2003. Nature 437:245-248

Blyth W, Bunn D, Kettunen J, Wilson T (2009) Policy interactions, risk and price formation in carbon markets. Energy Policy 37:5192-5207

Boorman DB, Hollis JM, Lilly A (1995) Hydrology of soil types: a hydrologically based classification of the soils of the United Kingdom. Institute of Hydrology Report No. 126. Institute of Hydrology, Wallingford

Bradbury NJ, Whitmore AP, Hart PBS, Jenkinson DS (1993) Modelling the fate of nitrogen in crop and soil in the years following application of ${ }^{15} \mathrm{~N}$-labelled fertilizer to winter wheat. J Agric Sci 121:363-379

> Bradley RI, Milne R, Bell J, Lilly A, Jordan C, Higgins A (2005) A soil carbon and land use database for the UK. Soil Use Manag 21:363-369

Byrne KE, Chojnicki B, Christensen TR, Drösler M and others (2004) EU peatlands: current carbon stocks and trace gas fluxes. CarboEurope GHG Report, November 2004. University of Tuscia, Viterbo

Coleman K, Jenkinson DS (1996) RothC-26.3: a model the turnover of carbon in soil. In: Powlson DS, Smith P, Smith JU (eds) Evaluation of soil organic matter models using existing long-term datasets. NATO ASI Series I, Vol 38. Springer, Berlin, p 237-246

Coleman K, Jenkinson DS, Crocker GJ, Grace PR, Klír J, Körchens M, Poulton PR, Richter DD (1997) Simulating trends in soil organic carbon in long-term experiments using RothC-26.3. Geoderma 81:29-44

Dersch G, Bohm K (1997) Austrian agriculture's share in the emission of trace gases affecting the climate. Bodenkultur 48:115-129

Falloon P, Smith P, Bradley RI, Milne R and others (2006) RothCUK - a dynamic modelling system for estimating changes in soil $\mathrm{C}$ from mineral soils at $1-\mathrm{km}$ resolution in the UK. Soil Use Manag 22:274-288

- Freeman C, Lock MA, Reynolds B (1993) Fluxes of $\mathrm{CO}_{2}, \mathrm{CH}_{4}$ and $\mathrm{N}$ from a Welsh peatland following simulation of water table draw-down: potential feedback to climatic change. Biogeochemistry 19:51-60

Funk DW, Pullman ER, Peterson KM, Grill PM, Billings WD (1994) Influence of water table on carbon dioxide, carbon monoxide, and methane fluxes from taiga bog microcosms. Global Biogeochem Cycles 8:271-278

Hall DG, Reeve MJ, Thomasson AJ, Wright VF (1977) Water retention, porosity and density of field soils. Technical Monograph No. 9, Soil Survey of England and Wales, Harpenden, p 32-42

Hargreaves KJ, Milne R, Cannell MGR (2003) Carbon balance 
of afforested peatland in Scotland. Forestry 76:299-317

Heidmann T, Christensen BT, Olesen SE (2002) Changes in soil $\mathrm{C}$ and $\mathrm{N}$ content in different cropping systems and soil types. In: Petersen SO, Olesen JE (eds) Greenhouse gas inventories for agriculture in the Nordic countries. Ministry of Food, Agriculture and Fisheries, Danish Institute of Agricultural Sciences, Report 81, Foulum, p 77-86

Hulme M, Jenkins GJ, Lu X, Turnpenny JR and others (2002) Climate change scenarios for the United Kingdom: the UKCIP02 scientific report. Tyndall Centre for Climate Change Research, School of Environmental Sciences, University of East Anglia, Norwich

IUCN UK Committee Peatland Programme (2010) Peatlands and greenhouse gas emissions reduction opportunities in Scotland. Briefing Note for the Scottish Government, available at www.iucn-uk-peatlandprogramme.org

Janssens IA, Freibauer A, Ciais P, Smith P and others (2003) Europe's terrestrial biosphere absorbs $7-12 \%$ of European anthropogenic $\mathrm{CO}_{2}$ emissions. Science 300:1538-1542

Jenkinson DS, Rayner JH (1977) The turnover of organic matter in some of the Rothamsted classical experiments. Soil Sci 123:298-305

Jenkinson DS, Hart PBS, Rayner JH, Parry LC (1987) Modelling the turnover of organic matter in long-term experiments at Rothamsted. INTECOL Bull 15:1-8

Joosten H (2009) The IMCG Global Peatland Database. International Mire Conservation Group, available at www. imcg.net/gpd/gpd.htm

King JJ, Franzmeier DP (1981) Estimation of saturated hydraulic conductivity from soil morphological and genetic information. Soil Sci Soc Am J 45:1153-1156

Kirkby KJ, Smart SM, Black HIJ, Bunce RGH, Corney PM, Smithers RJ (2005) Long-term ecological change in British woodland (1971-2001). Research Report 653, Natural England, Peterborough

Lilly A (1999) The use of inverse modelling and dipwell data in the calibration and evaluation of a soil water simulation model. Geoderma 90:203-227

Lilly A (2000) The relationship between field-saturated hydraulic conductivity and soil structure: development of class pedotransfer functions. Soil Use Manag 16:1-18

Lilly A, Matthews KB (1994) A soil wetness class map for Scotland: new assessments of soil and climate data for land evaluation. Geoforum 25:371-379

Lilly A, Towers W, Malcolm A, Paterson E (2004) Report on a workshop on the development of a Scottish Soils Knowledge and Information Base (SSKIB). Macaulay Land Use Research Institute, Aberdeen, 22 Sep 2004, available at www.macaulay.ac.uk/workshop/SSKIB/SSKIBWorkshop_ Report.pdf

Martikainen PJ, Nykiinen H, Aim J, Silvola J (1995) Changes in fluxes on carbon dioxide, methane and nitrous oxide due to forest drainage of mire sites of different trophy. Plant Soil 168-169:571-577

Milne R, Bradley RI, Jordan C, Brown TAW (2004) Development of an improved version of the soil carbon inventory for the UK LULUCF GHG Inventory. In: Milne R, Mobbs DC (eds) UK emissions by sources and removals by sinks due to land use, land use change and forestry activities report June 2004. CEH Report to Defra, Contract CEPG
1/GA01054, Centre for Ecology and Hydrology, Wallingford

Mobbs D, Dyson K (2009) Mapping carbon emissions \& removals for the land use, land use change \& forestry sector. Department of Energy and Climate Change, London, available at www.decc.gov.uk/media/viewfile.ashx?filepath =statistics/climate_change/1_20100122174557_e_@@_ mappingemissionslanduse.pdf\&filetype $=4$

Moore TR, Dalva M (1993) The influence of temperature and water table position on carbon dioxide and methane emissions from laboratory columns of peatland soils. J Soil Sci 44:651-664

Reay D, Sabine C, Smith P, Hymus G (2007) Spring-time for sinks. Nature 446:727-728

Scottish Government (2010) What is SRDP? Scottish Government, Edinburgh, available at www.scotland.gov.uk/ Topics/farmingrural/SRDP/WhatIs

Sleutel S, De Neve S, Hofman G (2003) Estimates of carbon stock changes in Belgian cropland. Soil Use Manag 19: 166-171

Smith P (2001) Soil organic matter modeling. In: Lal R (ed) Encyclopedia of soil science. Marcel Dekker, New York, NY, p 1-8

Smith JU, Smith P (2007) Environmental modelling. An introduction. Oxford University Press, Oxford

Smith JU, Bradbury NJ, Addiscott TM (1996a) SUNDIAL: a PC-based system for simulating nitrogen dynamics in arable land. Agron J 88:38-43

Smith P, Smith J, Flynn H, Killham K and others (2007a) ECOSSE: Estimating Carbon in Organic Soils - Sequestration and Emission. Scottish Executive, Edinburgh

Smith P, Chapman SJ, Scott WA, Black HIJ and others (2007b) Climate change cannot be entirely responsible for soil carbon loss observed in England and Wales, 1978-2003. Glob Change Biol 13:2605-2609

Smith P, Martino D, Cai Z, Gwary D and others (2007c) Policy and technological constraints to implementation of greenhouse gas mitigation options in agriculture. Agric Ecosyst Environ 118:6-28

Smith JU, Chapman SJ, Bell JS, Bellarby J and others (2009) Developing a methodology to improve soil C stock estimates for Scotland and use of initial results from a resampling of the National Soil Inventory of Scotland to improve the ECOSSE model: final report. Scottish Government, Edinburgh, available at www.scotland.gov.uk/Publications/ 2009/11/12090841/0

Smith J, Gottschalk P, Bellarby J, Richards M and others (2010a) Model to Estimate Carbon in Organic Soils Sequestration and Emissions (ECOSSE). User manual. Scottish Executive, Edinburgh, available at www.abdn.ac. uk/biologicalsci/staff/details/jo.smith

> Smith J, Gottschalk P, Bellarby J, Chapman S and others (2010b) Estimating changes in Scottish soil carbon stocks using ECOSSE. I. Model description and uncertainties. Clim Res 45:179-192

Stern N (2007) The economics of climate change: the Stern review. Cambridge University Press, Cambridge

UKCIP (UK Climate Impacts Programme) (2002) UKCIP02. UK Climate Impacts Programme, Oxford, available at www.ukcip.org.uk/

Proofs received from author(s): November 24, 2010 